\title{
R-Test Static Measurement of The 5-axis CNC Machining Centre Rotary Axis Kinematic Centre Error
}

Jerzy Jozwik ${ }^{1}$, Paweł Lonkwic ${ }^{2}$, Milan Saga ${ }^{3}$, Ivan Kuric ${ }^{3}$

${ }^{1}$ Mechanical Engineering Faculty, Lublin University of Technology, 36 Nadbystrzycka Street, 20-816 Lublin, Poland. E-mail: j.jozwik@pollub.pl

${ }^{2}$ The Institute of Technical Sciences and Aviation, The State School of Higher Education, 54 Pocztowa Street,

22-100 Chełm, Poland. E-mail: pawel.lonkwic@lift.pl

${ }^{3}$ Mechanical Engineering Faculty, University of Zilina, SK-010 01 Zilina, Slovak Republic.

E-mail: ivan.kuric@fstroj.utc.sk, milan.saga@fstroj.utc.sk

This paper presents static measurements results of the kinematic pair centre of the C-rotary axis of the 5-axis machine tool at digitised angle positions $\alpha$ of the machine rotary table. The measurements were conducted with the application of R-test calibration and measuring system. The article discusses the test sequence as well as the evaluation of the kinematic centre location of the rotary axis, relative to linear X, Y-axis. The summary formulates guidelines covering the compensation of the axis location. Measurement results were presented in diagrams and tables.

Keywords: manufacturing, errors of $\mathrm{CNC}$ machine tool, diagnostic systems, calibration, R-test

\section{References}

[1] FlORUSSEN, G.H.J., DELBRESSINE, F.L.M., MOLENGRAFT, M.J.G., SCHELLEKENS, P.H.J. (2001). Assessing geometrical errors of multi-axis machines by three-dimensional length measurements. In: Measurement, Vol. 30, pp. 241-255. Publisher Elsevier.

[2] FLORUSSEN, G.H.J., SPAAN, H.A.M. (2012) Dynamic R-test for rotary tables on 5-axes machine tools. 5th CIRP Conference on High Performance Cutting 2012. Procedia CIRP 1. In: Available online at www.sciencedirect.com. pp. $536-539$.

[3] HONG, C., IBARAKI, S., OYAMA, CH. (2012). Graphical presentation of error. motions of rotary axes on a fiveaxis machine tool by static R-test with separating the influence of squareness errors of linear axes. In: International Journal of Machine Tools \& Manufacture, Vol. 59. pp.24-33. Publisher Elsevier.

[4] IBARAKI, S., IRUTANI, T., MATSUSHITA, T. (2012). Calibration of location errors of rotary axes on five-axis machine tools by on-the-machine measurement using a touch-trigger probe. In: International Journal of Machine Tools \& Manufacture, Vol. 58, pp.44-56. Publisher Elsevier.

[5] JÓZWIK, J. Ocena odchyłki prostopadłości osi obrabiarki sterowanej numerycznie z wykorzystaniem systemu diagnostycznego QC10 Ballbar (2010). In: Advances in Science and Technology Research Journal, No.4. pp. 91102, Publisher: Society of Polish Mechanical Engineers and Technicians, Lublin.

[6] JÓZWIK, J., PIEŚKO, P., KRAJEWSKI, G. (2010). Evaluation of QC10 Ballbar diagnostics method for CNC machine. In: Maintenance and Reliability, No. 3, pp. 10-20. Publisher: Polish Maintenance Society, Warsaw.

[7] MAJDA, P. (2011). Pomiary i kompensacja błędów geometrycznych obrabiarek CNC. In: Inżynieria Maszyn, R. 16, z. 1-2. pp.126-135. Publisher: Wrocławska Rada FSNT NOT, Wrocław.

[8] MUDITHA DASSANAYAKE, K.M., TAJIMA, K., CUI, CH., TSUTSUMI, M. (2011). A New Device for Accuracy Measurements of Multi-axis NC Machines. In: The Second TSME International Conference on Mechanical Engineering. 19-21 October, 2011, Krabi, Thailand.

[9] ISO Standard: ISO 10791 Test conditions for machining centres.

[10] SPAAN, H.A.M., FLORUSSEN, G.H.J. (2012). Determining the 5-axes machine tool contouring performance with dynamic R-test measurements. In: Proceedings of the 12th euspen International Conference - Stockholm June 2012. IBS Precision Engineering, the Netherlands.

[11] TUREK, P., KWAŚNY, W., JĘDRZEJEWSKI, J. (2010). Zaawansowane metody identyfikacji błędów obrabiarek.In: Inżynieria Maszyn, R. 15, z. 1-2, pp.8-37. Publisher: Wrocławska Rada FSNT NOT, Wrocław,

[12] WEIKERT, S., KNAPP, W. (2004). R-Test, a New Device of Accuracy Measurements on Five Axis Machine Tools. In: CIRP Annals, Vol. 53. pp. 429-432. Publisher Elsevier. 
[13] MAYER, K., PEXA, M., PAVLU゚ , J. (2012). Impact of technical diagnostics interval on machinery maintenance. In: Manufacturing Technology, Vol. 12, No. 12, pp. 42-46. ISSN 1213-2489.

[14] KRYNKE, M., SELEJDAK, J., BORKOWSKI, S. (2012). Diagnosis and damage of bearings. In: Manufacturing Technology, Vol. 12, No. 13, pp.140-144. ISSN 1213-2489..

[15] NESLUŠAN, M., ROSIPAL, M., KOLAŘÍK, K.., OCHODEK, V. (2012). Application of Barkhausen Noise for Analysis of Surface Integrity after Hard Turning. In: Manufacturing Technology. Vol. 12, No. 12, p. 60-65.

[16] SVOBODA, M., SOUKUP, J. (2013). Verification of Numeric Solution by Experiment for Examination Vertical Oscillation of a Mechanical Systém. In: Manufacturing Technology. Vol. 13, No. 4, pp. 559-563.

[17] SVOBODA, M., SOUKUP, J. (2013). Dynamic Measurement of Four-Axle Railway Wagon. Manufacturing Technology. Vol. 13, No. 4, pp. 552-558.

\section{Paper number: M201434}

Copyright (C) 2014. Published by Manufacturing Technology. All rights reserved. 